\title{
Study Variable
}

National Cancer Institute

\section{Source}

National Cancer Institute. Study Variable. NCI Thesaurus. Code C142192.

A variable identified as relevant to a particular clinical study. 